\title{
THE PALIMPSEST
}

Edited by William J. Petersen

VoL. L Issued IN JULy 1969

No. 7

Copyright 1969 by The State Historical Society of Iowa

\section{ars}

\section{United States Patent Office}

Plato referred in his Republic to "necessity... [as] the mother of invention." Since then many people have been interested in the inventor, his inventions, and the protection of his rights by the granting of patents. A patent gives an inventor the right to exclude others from making or selling the invention covered by the patent. In other words, he has been granted a monopoly for the period of time stated in the patent.

Before the Constitution of the United States was adopted, many of the American colonies and states issued patents. The first patent was granted by the Massachusetts General Court to Samuel Winslow in 1641 for a new method of making salt. The same Court granted the first patent on machinery to Joseph Jenkes in 1646 for a mill to manufacture scythes. Unlike modern ones these early patents were issued only by special acts of the legislatures.

When the various state delegates met in Philadelphia in 1787 to draft a Constitution, one of 
their problems was the protection of inventors and authors. James Madison proposed that Congress have the power "to encourage by premiums and provisions, the advance of useful knowledge and discoveries." A proposal by Charles Pinckney of South Carolina would give the government the authority "to grant patents for useful inven tions.'

Article I, Section 8 of the United States Constitution as adopted gave Congress the right "to promote the progress of science and useful arts by securing for limited times to authors and inventors the exclusive right to their respective writings and inventions.'

When the second session of the First Congress convened in January 1790, George Washington addressed them. In his recommendations he stressed the importance of encouraging inventions:

The advancement of agriculture, commerce, and manufactures, by all proper means, will not, I trust, need recommendation but I cannot forbear intimating to you the expediency of giving effectual encouragement, as well to the introduction of new and useful inventions from abroad, as to the exertions of skill and genius in producing them at home.

Congress responded quickly and passed the first patent act on April 10, 1790. It defined an invention as "any useful art, manufacture, engine, machine, or device, or any improvement thereon not before known or used." The responsibility of granting patents was placed with a "Patent 
Board" consisting of the Secretary of State, the Secretary of War, and the Attorney General.

Thomas Jefferson, as Secretary of State, was the moving spirit of the Board. Being an inventor of considerable merit, he made a personal examination of all patent applications that came before the Board. The first patent was issued to Samuel Hopkins of Pittsford, Vermont, for an improvement in making potash. Three patents were issued the first year. A total of more than three million had been issued to 1968 .

On June 27, 1790, Jefferson wrote that the act authorizing "the issuing of patents for new discoveries has given a spring to invention beyond my conception." He summarized these discoveries for which patent applications were being made:

"Many of them indeed are trifling, but there are some of great consequence which have been proved by practice, and others which if they stand the same proof will produce great effect." The same could be said for those later inventions of Iowans.

New legislation was passed in 1793. An application was no longer examined for its novelty and usefulness. By the new "registration" system, a patent was granted to anyone who applied, submitted the proper drawings, and paid the necessary fee. The issuance became little more than a clerical function.

The Patent Act of 1836 re-established the 
American system of examining each application to determine if it had been invented or used before. When issued, the patent was good for fourteen years, subject to an extension of seven years. The application fee of $\$ 30$ was established. The Patent Office was established as a distinct and separate bureau in the Department of State. It was placed in charge of a Commissioner of Patents appointed by the President.

In 1839 the Commissioner was also assigned the duty of collecting and publishing statistics and other information on agriculture. The Patent Office continued this work until the Department of Agriculture was created in 1862.

The Patent Office was transferred in 1849 from the State Department to the newly created Department of the Interior. It remained there until 1925 when it came under the jurisdiction of the Department of Commerce.

In 1861 the term of a patent grant was increased from fourteen to seventeen years, without any extension of the time. Meanwhile, the fee was increased to $\$ 35$.

The Patent Office occupied many homes during the first twenty years. From 1810 to 1836 it was housed in Blodgett's Hotel. When the government purchased it in 1810, it had fallen into decay. It had never been finished nor occupied as a hotel.

This was the only government building which was not burned by the British in 1814. Dr. Wil- 
liam Thornton, who had designed the United States Capitol Building, was in charge of the Patent Office at the time. He told the British that burning what was useful to all mankind would indeed be a barbarous act.

When the Patent Office outgrew Blodgett's Hotel, Congress authorized in 1836 the construction of a new building. Its architecture was Gre cian Doric, the details being modeled after the Parthenon. The Patent Office continued to occupy this building until 1932. It is now the home of the National Portrait Gallery of the Smithsonian Institution.

The comments of two Americans sum up the importance of American inventive genius. Ralph Waldo Emerson wrote: "Invention breeds invention." Abraham Lincoln said, "The patent system added the fuel of interest to the fire of genius in the discovery of new and useful things." 